\title{
Teaching Helping Attitude among Adolescent Students
}

\section{Dr. Pranjal Buragohain}

Assistant Professor, Department of Education Dibrugarh University, Dibrugarh, Assam

\section{Mitali Sonowal, JRF}

Department of Education

Dibrugarh University, Dibrugarh, Assam

\begin{abstract}
Helping attitude is an established noble behavior or the degree of the concern for the welfare of the others with regard or disregards of rewards. The present paper is an attempt to focus on the role of helping attitude exercises on building helping attitude among adolescent students. Helping attitude has very significant implications on the social and subjective well- being. Despite such significance, positive trait like helping attitude has been getting less importance in scientific psychological study. So, present paper is an effort to bridge such gaps in Indian context. Researches, conducted in the field of Positive Psychology support that traits like helping attitude reflects the practice of human strengths in social phenomenon as well as ethical strength of a society. Therefore, it is necessary to develop certain skills to build helping attitude in a scientific way. The researcher developed certain exercises of building helping attitude and experimented on a group of adolescent students. It was evident from the present research that helping attitude can be significantly taught and learnt through these exercises.
\end{abstract}

Keywords: Helping attitude, helping attitude exercise, adolescent

\section{INTRODUCTION}

Helping Attitude is a willingness and concern for the welfare of others. It refers to voluntary actions intended to help others, may be in lieu of money or some returns or purely selfless help. In simple words, it is caring about the welfare of other people and acting to help them. Altruistic behavior can be motivated by personal egotism or it can be prompted by "pure" empathetic desire to benefit another person, irrespective of personal gain (Batson, 1991; Batson, Ahmed \& Lishner, 2009). With the positive attitudes like helping attitude a person enjoys 'helping' others and also can reduce many different negative emotions of their day by day life. Thus, it seems that helping behaviours could be considered as beneficial for the person who helps because it is likely that the person who helps another person will experience the joys of helping others.

Helping attitude is the quality of individual which benefits the giver as well as the receiver. It is the quality of unselfish concern for the welfare of others not putting themselves first but being willing to give their time or money or effort etc. for the benefits of others. Such helps can enhance the positive thought and positive self-esteem. On the other hand, people's helping attitude involves expectation or exchange of material goods as well as social goods like service, love, information status. (Baron \& Byrne, 1999).

The study of Helping Attitude has its root in the works of early Social psychologists. Research conducted over the last few years has shown that the positive emotions and attitudes like optimism, helping attitude, love, and hope have tremendous impact on well-being but the study of positive attitude and emotions have a very short past. Because most of the time the study of negative aspects like schizophrenia, truancy, alcoholism etc have been getting more importance.

\subsection{Factors Affecting Helping Attitude}

Helping is the function of either relatively selfish or relatively unselfish motives. (Baron \& Byrne, 1999). For centuries, it was assumed that all human behavior, including the helping of others, is egoistically motivated. The term Egoism refers to the selfish motive to pursue some sort of personal gain or benefits through targeted behavior such as helping others. But all the times, under some circumstances, the egoism motives account for the helping. On the other hand, empathy is an emotional response that refers to feelings of compassion, sympathy, tenderness and the like or to perceive plight of another person without any selfish motives. For the empathy people help those in need simply because it feels good to do so. The investigators now turns to the four major theories that attempt to explain pro-social motivation. 
- Empathy Altruism Hypothesis: The empathy altruism hypothesis states that feelings of empathy for another person produce on altruistic motivation to increase that person's welfare. In the empathy altruism hypothesis the term Empathy refers to compassionate feelings which is generally perceived to be a cause of leading to helping behavior. Since for the arousal of empathy person provides help simply because victim needs help and because it feels good to provide help. One view of empathy is that it involves the ability to match another persons' emotion. Altruism refers to a motivational state in which the goal increases another persons' welfare as an end in itself. Hence, this motivation to help can be sufficiently strong that the individual who provides help is willing to engage in unpleasant, dangerous and even life-threatening activity. (Baron \& Byrne, 1999). On this underlying assumption, Batson and his colleagues (2009) proposed the empathy altruism hypothesis. This theory predicts that those feeling high level of empathy for a person in need will be more likely to help than will those feeling less empathy.

- Negative State Relief Model: this theory suggests that when a person is experiences negative affect he helps, sometimes because he wants to make himself feel better. This explanation of prosocial behaviour is known as the negative state relief model. (Batson et all, 2009). When negative affect is aroused person provides help in order to reduce own negative affect and make the helper feel better.

- Empathetic Joy Hypothesis: It is generally true that it feels good to have a positive impact on other people. Helping others brings good feelings to the giver and receiver of the deeds because receiver will pleased that someone cares, and looks out for him, and giver will become satisfied and inside his heart for helping someone from his own will. It can literally be better to give than to receive. By helping one individual can enjoy a self-esteem boost for making others lives better, and make the world a better place. It is due to the empathetic joy person provides help in order to engage in an activity that has a successful outcome making the helper feel good.

- Genetic Determinism Model: The proposal that behavior is driven by genetic attributes that evolved because they enhanced the probability of transmitting one's genes to subsequent generations. (Baron \& Byrne, 1999).this model suggests that unconscious desire to help occurs if the person perceives the victim to be genetically similar to himself or herself. People help if the individual feels emotionally close relative is perceived as rational ethical and a matter of obligation.

\subsection{Potential Advantages of Helping}

Helping behavior in children and adults has received considerable interest in the last few years, but the potential advantages of encouraging helping behavior in young children have yet to be examined. What might children learn from helping others or from being helped by others? What significance might helping have for children, the classroom, or even society?

A personal benefit to the child who helps others would be the sense of competence in assisting others. White (1960) and others have referred to a key motivational disposition which is central to psychologically healthy development. "Effectance motivation" is the desire to feel potent and competent in dealing with one's physical and social worlds. Ideally, children become increasingly able to meet their own needs and to change those aspects of their world that are dissatisfying. This is in contrast to the child who feels that whatever he or she touches leads to disaster and who is a passive (reactive) agent in his or her own development. The isolate, for example, has little chance to feel effectance in dealing with people and fails to reap the motivational benefits of working cooperatively with others.

Children who do not help also have no chance to gauge the needs of others for help. Sensitivity to the "need for help" cues others give is probably an outcome of the shift from an egocentric concern for one's own needs and perceptions to a socio-centric concern for others' needs. The beginnings of friendships may entail a reciprocal trading of help, and one would find it difficult to imagine a lasting friendship that is not characterized by such mutuality. Helping may be perceived by friends as a reliable alliance in times of stress and as a sign of affection.

There are also advantages in learning to receive help from others. It is likely that every child will meet situations in which he or she needs comfort or support or help with a task. The child or adult who is unwilling or unable to accept help from others is likely to suffer needlessly, or to cause suffering in those people who are close. Coping with life's stresses is made easier when others lend a hand. 
The benefits to the classroom as a mini-society are at least twofold. The kind of atmosphere that is likely to arise from greater helping behavior is likely to be friendlier and more supportive. The relationship between classroom achievement and a positive (e.g., warm, helping) class-room climate has been found positive (Gazda et al. 1973).

Empathy which is typically defined as a vicarious affective response to another's feelings (Stotland, 1969), is another important factor which determines helping behavior. Feeling empathy for someone in distress appears to increase the desire to help that person. It signifies an observer's emotional response to the perceived welfare of someone else in some particular situation.

\section{Statement of the Problem}

The problem under study is formally entitled as "Teaching Helping Attitude among Adolescent Students"

\section{SigNifiCANCE OF THE STUdY}

During adolescence there is a growing shift of influence from the family to peers as a reference group. Personal and social factors become more important in their every activity. Attitude, being acquired characteristics, is mostly developed in adolescents through school and society. Therefore, with the new attitude these young people, in our society exhibit the greatest conflict as to who they are and where they belong in the world. Thus, adolescence is a critical periods for attitude development. The adolescent is caught in a conflict between identification with role of a child (from which he is emerging) and the role of an adult (which is beginning assume) and this is resolved by him by involvement in the peer group. And in such situation, they become increasingly concerned with what peers think, which sometimes can keep them from acting. If peers are engaging in a lot of helping behavior, the other would tend to imitate them.

Since, we can say that, human are inherently sociable, capable of empathy that one person will help another when problems arise. When people interact with each other in social relationships, they are always pro-social, usually helpful, and often altruistic. Hence, it is fact that people frequently are willing to help those in need. But as the human life become mechanical, the study of positive aspect of human life such as helping attitude has great rational in the present context. It is evident from a good stuff of research stated earlier that helping attitude can potentially increase positive personal and social outcomes. Thus, it demands serious research to broaden up and replicate the findings in an economically, geographically and demographically new setting.

Recent researches conducted by Seligman (2013), Emmons (2008), Fredrickson (2009), Lyubomirsky (2012) discovered that the strengths of life are skill based and can be built methodically. The researchers adapted some skills and exercises from the studies conducted by Seligman (2013), Emmons (2008) and implemented locally. The researchers found that gratitude (Buragohain \& Mandal, 2015 \& Buragohain \& Mandal, 2016) and hope Buragohain, 2014; Buragohain \& Bordoloi, 2015) can be measurably taught to adolescents through certain exercises. On the basis of these findings the researchers decided to do similar experiment on helping attitude on adolescent's students.

Lack of study on the positive aspects of life like helping, gratitude, hope, resilience, savour, self efficacy, happiness, etc. keeps the society unaware of their positive impacts. In this context the present study will through some light on helping attitude as one of the positive aspects of life and its credit as altruistic behavior. So, keeping view the significance of helping attitude the present study is an attempt to test the impact of helping attitude exercises in building helping attitude among the adolescents.

\section{OBJECTIVES}

The objectives of the study were-

4.1. To compare the level of helping attitude between male and female adolescent students before the helping attitude exercises.

4.2. To compare the level of helping attitude between male and female adolescent students after the helping attitude exercises.

4.3. To study the significance of change of the level of helping attitude of the adolescent students after the helping attitude exercises. 
4.4. To study the significance of change of the level of helping attitude of the male adolescent students after the helping attitude exercises.

4.5. To study the significance of change of the level of helping attitude of the female adolescent students after the helping attitude exercises.

\section{HYPOTHESES}

$\mathbf{H}_{\mathbf{1}}$. There is no significant difference in the level of helping attitude between male and female adolescent students before the helping attitude exercises.

$\mathbf{H}_{2}$. There is no significant difference in the level of helping attitude between male and female adolescent students after the helping attitude exercises.

$\mathbf{H}_{3}$ - There is a significant progress in the level of helping attitude of the adolescent students after the helping attitude exercises.

$\mathbf{H}_{\text {4. }}$ There is a significant progress in the level of helping attitude of the male adolescent students after the helping attitude exercises.

$\mathbf{H}_{5}$ - There is a significant progress in the level of helping attitude of the female adolescent students after the helping attitude exercises.

\section{DeFinition OF THE KeY TERM}

\subsection{Helping Attitude}

Helping attitude is degree of the concern for the welfare of the others with regard or disregards of rewards. The level of helping attitude in the present study was quantified by using Helping Attitude Scale developed by Gary S. Nickell (Moarhead State University) and adapted by the Investigators. More the scores in the scale refer more the level of helping attitude.

\subsection{Helping Attitude Exercise}

Helping attitude exercises in the present study is operationally defined as the exercises or activities which inspire helping motives of an adolescent. Help journey and helping attitude inspiring story are the helping attitude exercises in the present study.

\subsection{Adolescence}

Adolescence is defined as the participants of age group between 12 to 18 . In the present study, the researcher will include the students of class nine and ten which are belong to this age level and will be considered as adolescent.

\section{Methodology}

\subsection{Participants}

The participants selected for the investigation comprised of 32 adolescent students studying in Bhakat Chapori High School, Majuli, Assam.

\subsection{Design}

The present study is an experimental study. The researchers decided to use quasi experimental single group pre-test post-test design to meet the objectives. A residential camp was organized for seven days and the investigators arranged for the helping attitude exercises for the adolescent students along with other curricular areas. A helping attitude test was conducted on the adolescent students before introducing the helping attitude exercises. After nine days of exercises the levels of helping attitude of the students were re-tested and the significance of difference of the mean scores of both the tests were calculated to get the result of introducing the helping attitude exercises.

\subsection{The Tool Used}

Helping Attitude Scale developed by Gary S. Nickell (1998), Moarhead State University was used for the study. This scale consists of 19 statements which includes 14 positive, and 5 negative items. The range of scores on this scale extended from 20 to 95 with a neutral score of 60 . The summation of all 19 scores earned by a student on all statements was taken as the total Helping Attitude score. The reliability coefficient of the original scale was 0.847 which was calculated by test-retest method and the reliability coefficient of the translated version of the scale was 0.77 which was calculated by split half method. 


\subsection{Statistical Technique}

The Researchers used ' $t$ ' test to estimate the significance of difference between mean scores.

\subsection{Variables}

a. Independent variable: In the present sturdy the helping attitude exercise is the independent variable.

b. Dependent/observed variable: Dependent variable in the present study is the level of helping attitude.

\section{The Treatment}

\subsection{Help Journey}

The exercise was designed by the researchers. In this exercise the researchers instructed to the adolescents- "Count the helps received from others and also to find at least one opportunity to help somebody. Do it every day. In the evening when you come back to your room or study table write the details of the help received and provided. Keep an extra copy for this work. Try to write "what did you feel" when you received a help from others. Try to write "what did you observe" in the behavior of the person when you offered a helping behavior. Try to write "what did you feel" when you have seen that somebody has been benefited by your behavior. The researchers inspired adolescents to do this exercise for nine days in the experimental camp. The researchers further instructed that- "There is no right way to write these. Not necessary to think of a good, handy diary book. Don't be bothered about spelling or grammar mistakes. The point is, you develop a habit of paying attention to the helps and goods you offered and received. Pay attention on the feeling (benefits) you received and offered from the helping behaviours."

\subsection{Helping Attitude Inspiring Story}

The exercise was designed by the researchers. The researchers selected and developed some stories and anecdotes narrating utmost sense of helping attitude. Some characters have been developed in the stories having serious need of help and some characters who offered help. The researchers developed stories in such a way where the help provided by one person has changed life of another in a significant way. The feeling of both the sides i.e. the giver and the receiver are analyzed in a positive way in the stories. In short the stories are helping attitude inspiring stories. The researcher altogether developed five stories and two anecdotes and narrated to the group of the adolescents as a helping attitude exercise. The researcher further told the students to express their feeling after hearing the stories and anecdotes. The exercise was continued for nine days along with the help journey.

\section{ANALYSIS AND INTERPRETATION}

\subsection{Hypothesis 1}

There is no significant difference in the level of helping attitude between male and female adolescent students before the helping attitude exercises.

Table1. Significance of difference in the level of helping attitude between male and female adolescent students before the helping attitude exercises

\begin{tabular}{|c|c|c|c|c|c|c|c|}
\hline Group & N & Mean & S.D & SED & t & df & Inference \\
\hline Male adolescents & 16 & 64.44 & 8.59 & & & & $\begin{array}{c}\text { Not significant at } 0.01 \\
\text { level of significance }\end{array}$ \\
\hline Female adolescents & 16 & 62.31 & 7.03 & 2.76 & .772 & 30 & \\
\hline
\end{tabular}

Table -1 shows that the $t$ value is .772 which is less than the table value 2.75 at 0.01 level of significance. Thus, thee null hypothesis is accepted and it is concluded that there is no significant difference between male and female adolescent students in the level of helping attitude before helping attitude exercise.

\subsection{Hypothesis 2}

There is no significant difference in the level of helping attitude between male and female adolescent students after the helping attitude exercises.

Table2. Significance of difference in the level of helping attitude between male and female adolescent students after the helping attitude exercises

\begin{tabular}{|c|c|c|c|c|c|c|c|}
\hline Group & N & Mean & S.D & SED & t & df & Inference \\
\hline Male adolescents & 16 & 72.31 & 5.45 & \multirow{2}{*}{16} & \multirow{2}{*}{344} & 30 & $\begin{array}{c}\text { Not significant at } 0.01 \\
\text { level of significance }\end{array}$ \\
\hline Female adolescents & 16 & 71.69 & 4.84 & 1.8 & .344 \\
\hline
\end{tabular}




\section{Dr. Pranjal Buragohain \& Mitali Sonowal, JRF}

Table -2 shows that the $\mathrm{t}$ value is .344 which is less than the table value 2.75 at 0.01 level of significance. Thus the null hypothesis is accepted and it is concluded that there is no significant difference between male and female adolescent students in the level of helping attitude after helping attitude exercise.

\subsection{Hypothesis 3}

There is a significant progress in the level of helping attitude of the adolescent students after the helping attitude exercises. Here the directional hypothesis is converted to following null hypothesis for statistical analysis.

"There is no significant progress in the level of helping attitude of the adolescent students after the helping attitude exercises."

Table3. Significance of change in the level of helping attitude of the adolescent students after the helping attitude exercises

\begin{tabular}{|c|c|c|c|c|c|c|c|c|}
\hline Group & N & Mean & S.D & SED & r & t & df & Inference \\
\hline Pre-test & 32 & 63.38 & 7.79 & & & & & $\begin{array}{c}\text { significant at } 0.01 \\
\text { level of significance }\end{array}$ \\
\hline Post-test & 32 & 72 & 5.08 & 1.96 & 0.56 & 4.4 & 62 &
\end{tabular}

Table -3 shows that the $\mathrm{t}$ value is 4.4 which is greater than the table value 2.39 at 0.01 level of significance. Thus, the null hypothesis is rejected and it is concluded that there is a significant progress in the level of helping attitude of the adolescent students after the helping attitude exercise.

\subsection{Hypothesis 4}

There is a significant progress in the level of helping attitude of the male adolescent students after the helping attitude exercises. The directional hypothesis is converted to following null hypothesis for statistical analysis -

"There is no significant progress in the level of helping attitude of the male adolescent students after the helping attitude exercises."

Table4. Significance of change in the level of helping attitude of the male adolescent students after the helping attitude exercises

\begin{tabular}{|c|c|c|c|c|c|c|c|c|}
\hline Sex & N & Mean & S.D & SED & r & t & df & Inference \\
\hline Male adolescents (Pre-test) & 16 & 64.44 & 8.59 & & & & & $\begin{array}{c}\text { significant at } 0.01 \\
\text { level of significance }\end{array}$ \\
\hline Male adolescents (Post-test) & 16 & 72.31 & 5.45 & 2.87 & 0.62 & 2.74 & 30 &
\end{tabular}

Table -4 shows that the $t$ value is 2.74 which is greater than the table value 2.46 at 0.01 level of significance. Thus, the null hypothesis is rejected and it is concluded that there is a significant progress in the level of helping attitude of the male adolescent students after the helping attitude exercise.

\subsection{Hypothesis 5}

There is a significant progress in the level of helping attitude of the female adolescent students after the helping attitude exercises. The directional hypothesis is converted to null hypothesis for statistical analysis -

"There is no significant progress in the level of helping attitude of the female adolescent students after the helping attitude exercises."

Table5. Significance of change in the level of helping attitude of the female adolescent students after the helping attitude exercises.

\begin{tabular}{|c|c|c|c|c|c|c|c|c|}
\hline Test & N & Mean & S.D & SED & r & t & df & Inference \\
\hline Female adolescents (Pre-test) & 16 & 62.31 & 7.03 & & & & & $\begin{array}{c}\text { significant at } 0.01 \\
\text { level of significance }\end{array}$ \\
\hline Female adolescents (Post-test) & 16 & 71.69 & 4.84 & 2.69 & 0.47 & 3.49 & 30 &
\end{tabular}

Table -5 shows that the $t$ value is 3.49 which is greater than the table value 2.46 at 0.01 level of significance. Thus, the null hypothesis is rejected and it is concluded that there is a significant progress in the level of helping attitude of the female adolescent students after the helping attitude exercises. 


\section{MAJOR FINDINGS}

10.1. There is no significant difference in the level of helping attitude between male and female adolescent students before the helping attitude exercises.

10.2. There is no significant difference in the level of helping attitude between male and female adolescent students after the helping attitude exercises.

10.3. There is a significant progress in the level of helping attitude of the adolescent students after the helping attitude exercises.

10.4. There is a significant progress in the level of helping attitude of the male adolescent students after the helping attitude exercises.

10.5. There is a significant progress in the level of helping attitude of the female adolescent students after the helping attitude exercises.

Thus, from the above findings it is evident that the helping attitude exercise can significantly change the level of helping attitude of the adolescent students. It is further concluded that helping attitude can significantly be taught and learnt through exercises.

\section{Conclusion}

Helping Attitude is the quality of individual which benefits the giver as well as the receiver and work as a strong pro-social behavior. So it is an urgency to develop certain scientific skills to cultivate this virtue. It is discovered that the virtues and strengths of life can be significantly taught and learnt through exercises. Therefore, two helping attitude exercises viz. 'help journey' and 'helping attitude inspiring story' were developed by the researchers and experimented on a group of adolescents. It is evident in the study that the helping attitude exercises can significantly improve the level of helping attitude of the adolescent students. It is further concluded that helping attitude can significantly be taught and learnt through exercises.

\section{REFERENCES}

Baron, A.R., \& Byrne, D. (1999). Social Psychology. New Delhi: Prentice hall of India Pvt. Ltd.

Batson, C.D. (1991). The Altruism question: Towards a Social- Psychological Answer. Hillsdale, NJ: Lawrence Erlbaum.

Batson, C.D., Ahmed, N. \& Lishner, D.A. (2009). Empathy and Altruism. In S.J. Lopez \& C.R. Snyder (Eds), Oxford Handbook of Positive Psychology (pp.417-426). New York: Oxford University Press

Buragohain, Pranjal (2014). A study of the impact of Hope Exercise in Building Hope among the Students of Secondary School. International Journal of Humanities, social science and Education. 1(11), 54-60.

Buragohain, P. and Mandal, R. (2015). Teaching of Gratitude among the Students of Secondary School as a means of well-being. International Journal of Humanities, social science and Education.(IJHSSE). 2(2), 179-188.

Buragohain, P. and Mandal, R. (2016). Can Gratitude be taught: an experiment on the students of Mahapurusha Srimanta Sankardeva University (MSSU). Nagaon, Assam. International Journal of Research and Scientific Innovation (IJRSI) III (II), 24-28.

Buragohain, P. and Bordoloi, p. (2015). Teaching of Hope among the Students of Secondary Schools as a means of Success and Well-Being. International Journal of Social Development. 2 (3), 1-8.

Csikszentmihalyi, Mihaly (1990) Flow: The Psychology of optimal Experience. New York: Harperperennial.

Emmons, R.A. (2008). Thanks! How Practicing Gratitude can make you Happier. New York: Houghton Mifflin Company.

Fredrickson, B. (2009). Positivity: Top Notch Research reveals the 3 to 1 ratio that will change your life. New York: Three Rivers Press.

Gazda, G., Asbury, F., Balzu, F., Childers, W. C., Dessille,W., and Walters, R. (1973). A General Review of Related Research Literature. Marcus., R. F, and Leiserson, M. (1978). Encouraging Helping Behavior Young Children, National Association for the Education of Young Children (NAEYC). Vol. 33, No. 6 pp. 24-34. 
Lyubomirsky, S. (2012). The How of Happiness. New York: Penguine.

Nickel, G.S (1998). The Helping Attitude Scale. Paper Presented at $106^{\text {th }}$ Annual Convention of the American Psychological association at San Francisco.

Seligman, M.E.P. (2013). Flourish: a Visionary new understanding of happiness and Well-Being, New York: Free Press.

Snyder, C. R., Lopez, J.S. \& Pedrotti, J. T. (2011). Positive Psychology: The Scientific and Practical Exploration of Human Strengths. New Delhi: Sage Publication India Pvt. Ltd.

Stotland, E. (1969). Exploratory studies of empathy. In L. Berkowitz (Ed.), Advances in Experimental Social Psychology (Vol.4). New York: Academic Press. pp.271-314.

White, R. W. (1960). Competence and the Psychosexual Stages of Development. In Marcus., R. F, and Leiserson, M. (1978). Encouraging Helping Behavior Young Children, National Association for the Education of Young Children (NAEYC). Vol. 33, No. 6, 24-34.

\section{AUTHORS' BIOGRAPHY}

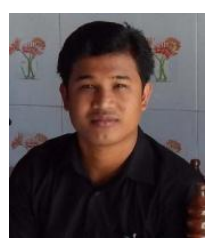

Pranjal Buragohain, is Assistant Professor, Department of Education Dibrugarh University, Dibrugarh, Assam is an Academician, play-write and Director. Area of interest is Positive Psychology, Positive Education and Philosophy of Education.

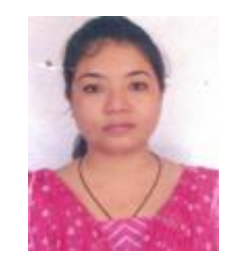

Mitali Sonowal, is Research Scholar, Department of Education, Dibrugarh University, Dibrugarh, Assam is pursuing research in the field of Cognitive Psychology. 